\title{
MENUJU DESA TANGGUH BENCANA (DI DESA SIRNOBOYO)
}

\section{AGOES HENDRIYANTO, NIMAS PERMATA P}

rafid.musyffa@gmail.com

\begin{abstract}
Abstrak: Bencana alam rutin yang dialami oleh masyarakat desa Sirnoboyo adalah bencana banjir yang banyak sekali kerugiannya yang pertama berdampak terhadap hasil pertanian dan merusak infrastruktur jalan dan jembatan. Kerugian dapat dikurangi dengan jalan menjadikan desa Sirinoboyo menuju Desa Tangguh Bencana. Untuk menuju Desa Tangguh Bencana dibutuhkan dana dan keseriusan pemerintah dalam rangka merubah skema pemikiran masyarakat yang merasa bahwa pembangunan memerlukan suatu kerja keras, gotong royong dan kebersamaan. Tujuan yang ingin dicapai dalam pengabdian ingin melihat sejauh mana Bentuk kemandirian masyarakat Desa Sirnoboyo untuk mewujudkan Desa Tangguh bencana yang diwujudkan dalam Rencana Penanggulangan Bencana Desa Sirnoboyo

Desa Tangguh Bencana di bagi menjadi 3 berdasarkan indikator yang telah ditetapkan. Sirnoboyo masuk katagori Desa tangguh Bencana Pratama dengan skor 31 dari 60 indikator. Untuk menuju Desa tangguh Bencana madya dan Utama memrlukan suatu perencanaan pembangunan dan kerja keras selurh elemen masyarakat untuk meningkatkan kesejahteraan masyarakat yang pada akhirnya akan meningkatkan kepedulian masyarakat terhadap arti pentingnya penaggulangan bencana. Rasa persaudaraan, kesetiakawanan, dan kekeluargaan masyarakat desa Sirnoboyo perlu ditingkatkan lagi guna mencapai Desa tangguh Bencana utama.
\end{abstract}

Kata Kunci: Desa, Tangguh Bencana

\section{PENDAHULUAN}

Merujuk pada Misi Program Pengabdian Kepada masyarakat DITLITABMAS Dikti yaitu menciptakan peradaban dan nilai-nilai kehidupan baru bagi masyarakat luas dan juga masyarakat kampus. Dengan demikian, prinsip transfer ilmu pengetahuan dan teknologi dari masyarakat kampus ke masyarakat sekitar dapat terpenuhi. Dengan demikian akan mengalir suatu ide, pikiran, inovasi yang kresatif dari masyarakat kampus yang dapat digunakan sebagai pemecahan masalah di lingkungan masyarakat. Dengan demikian pengabdian masyarakat oleh sivitas akademika STKIP PGRI Pacitan merupakan wujud respon terhadap dinamika kehidupan masyarakat yang senantiasa berkorelasi erat dengan berkembangnya persoalan, kebutuhan dan tantangan yang dihadapi.

Kalau kita lihat wilayah desa Sirnoboyo yang memiliki dua sungai, dari laut berjarak dua km dan termasuk daerah dataran rendah dengan ketinggian di atas permukaan laut empat (4) meter sampai enam (6) meter di atas permukaan laut 
Transformasi, Vol. 13, No. 1, Januari 2017: 1 - 13

merupakan daerah rawan bencana. Dengan melihat jumlah penduduk desa Sirnoboyo berjumlah 4327 orang cukup besar untuk ukuran sebuah desa di Kabupaten Pacitan.

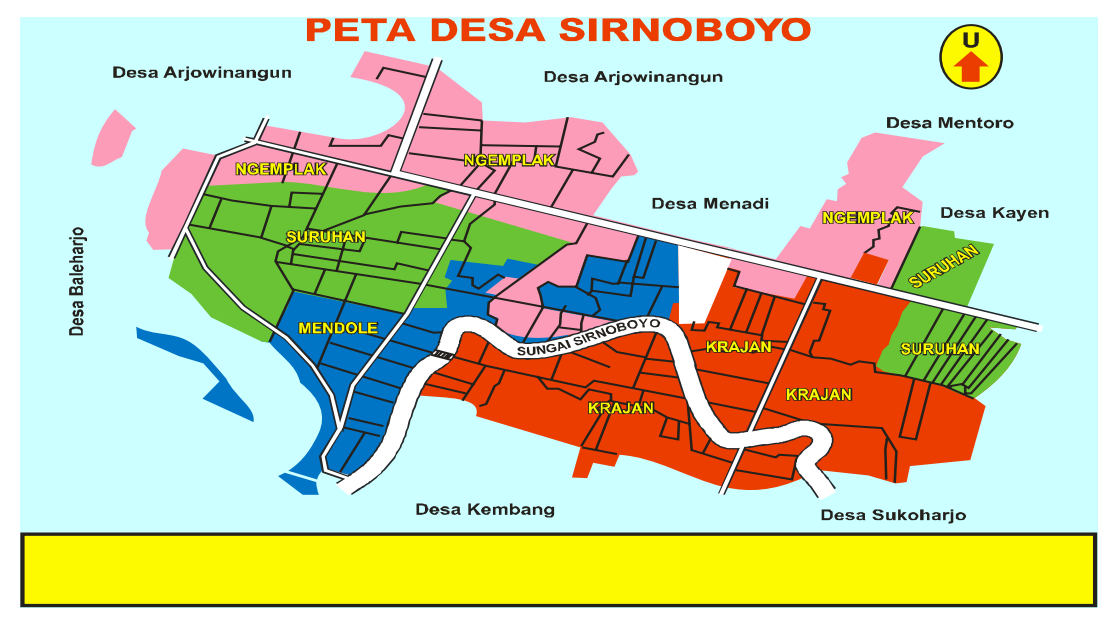

Gambar 1. Peta Desa Sirnoboyo

Berdasarkan gambar 1 dan 2 perencanaan bencana alam yang mengintai paling utama di Desa Sirnoboyo adalah bahaya gempa dan tsunami dikarenakan letak geografis Teluk Pacitan yang berhadapan langsung dengan zona subduksi di lepas pantai selatan Jawa. Prasarana penanganan bencana di wilayah perencanaan sudah banyak dilakukan salah satunya adalah dengan menyediakan jalur evakuasi. Jalur evakuasi yang direncanakan adalah jalan menuju perbukitan di bagian timur dan barat serta ke bagian utara wilayah perencanaan menuju Kota Pacitan.

Sedangkan untuk prasarana sistem peringatan dini telah dibangun di Kabupaten Pacitan secara keseluruhan. Bencana lainnya yang juga mengintai adalah bencana banjir di Desa Sirnoboyo, Sirnoboyo dan Kelurahan Ploso akibat meluapnya Sungai Grindulu. Saat ini tanggul penahan banjir sudah terpasang di sepanjang Sungai Grindulu. Sehingga untuk mengoptimalkan perannya perlu adanya pemeliharaan terhadap tanggul yang sudah ada sehingga dapat bertahan pada saat Sungai Grindulu meluap. Selain itu juga Desa Sirnoboyo dilewati Sungai Kebonagung yang sangat rawan jika meluap. Faktor utama yang menjadi faktor yang harus segera diperhatikan oleh pemerintah tanggul sebelah selatan hanya 


\section{Agoes Hendriyanto, Nimas Permata P, Menuju Desa...}

berupa tanggul pondasi batu yang ketinggiannya hanya 2 meter yng telah berusia 20 tahun.

Secara umum rencana sistem penanganan bencana di wilayah perencanaan adalah:

1. Mengoptimalkan Sistem Peringatan Dini yang telah terpasang

2. Melakukan pengaturan kepadatan permukiman pada zona permukiman kepadatan rendah

3. Meyediakan jalur evakuasi dengan menggunakan jaringan jalan arteri, kolektor dan lokal

4. Melakukan pemeliharaan tanggul Sungai Girindulu

Selain bencana banjir ada lagi bencana yang dapat melanda desa Sirnoboyo yaitu adanya tsunami dari laut karena jaraknya dari pantai sekitar dua kilometer. Untuk itu maka perlu adanya kesadaran masyarakat Sirnoboyo akan bahaya dari Tsunami untuk itu maka perlu adanya penyuluhan masyarakat untuk mempersiapkan segala sesuatunya sehingga dampak yang ditimbulkannya dapat diminimalkan. Sebenarnya telah dibentuk Forum Pengurangan Resiko Bencana baik tingkat Desa maupun tingkat dusun. Tetapi hanya sebatas Forum tetapi pelaksanaan dilapangan belum pernah melakukan simulasi bencana secara rutin hal ini disebabkan alasan pemdanaan yang sangat terbatas karena masyarakat belum sadar akan perlunya perencanaan dan penaggulangan bencana. untuk itu diperlukan suatu usaha yang keras khususnya untuk merubah kebiasaan masyarakat sebagai contohnya membuang limbah rumah tangga dan pertanian dengan seenaknya saja tanpa peduli terhadap lingkungan. Apalagi peran dari pemerintahan Kabupaten Pacitan hanya sebatas pembentukan suatu Forum Pengurangan Resiko Bencana setelah itu dibiarkan ertahun-tahun. sehingga tidak ada kegiatan yang dilakukan secara kontinu oleh sukarelawan yang ada di desa Sirnoboyo.

Sebenarnya jika bencana terjadi akan menghancurkan hasil-hasil pembangunan yang diperoleh dengan susah payah seperti jalan desa, sarana olahraga, tanggul, pertanian serta dana yang digunakan untuk tanggap darurat dan pemulihan pasca bencana juga telah mengurangi anggaran yang seharusnya 
dapat dimanfaatkan untuk membangun yang telah direncanakan di RPJM Desa serta program-program pemberantasan kemiskinan. Masyarakat miskin dan kaum marjinal yang tinggal di kawasan rawan akan menjadi pihak yang paling dirugikan, karena jumlah korban terbesar biasanya berasal dari kelompok ini dan pemiskinan yang ditimbulkan oleh bencana sebagian besar akan menimpa mereka

Bentuk pengabdian ini akan digunakan untuk mengelompokan Desa Sirnoboyo sebagai Desa tangguh Bencana atau belum, membuat Peraturan Desa tentang Desa tangguh Bencana, Meningkatkan kemandirian masyarakat Desa Sirnoboyo untuk mewujudkan Desa Tangguh bencana alam yang diwujudkan dalam Rencana Penanggulangan Bencana Desa yang diwujudkan dalam RPJM Desa Sirnoboyo.

\section{PEMBAHASAN}

Undang-Undang Republik Indonesia Nomor 24 Tahun 2007 Tentang Penanggulangan Bencana mengatur Hak Dan Kewajiban Masyarakat Pasal 26 yang menjelaskan, hak masyarakat dalam penangulangan bencana: 1) Setiap orang berhak; mendapatkan perlindungan sosial dan rasa aman, khususnya bagi kelompok masyarakat rentan bencana; mendapatkan pendidikan, pelatihan, dan ketrampilan dalam penyelenggaraan penanggulangan bencana; mendapatkan informasi secara tertulis dan/atau lisan tentang kebijakan penanggulangan bencana; berperan serta dalam perencanaan, pengoperasian, dan pemeliharaan program penyediaan bantuan pelayanan kesehatan termasuk dukungan psikososial; berpartisipasi dalam pengambilan keputusan terhadap kegiatan penanggulangan bencana, khususnya yang berkaitan dengan diri dan komunitasnya; dan melakukan pengawasan sesuai dengan mekanisme yang diatur atas pelaksanaan penanggulangan bencana. 2) Setiap orang yang terkena bencana berhak mendapatkan bantuan pemenuhan kebutuhan dasar. 3) Setiap orang berhak untuk memperoleh ganti kerugian karena terkena bencana yang disebabkan oleh kegagalan konstruksi. 


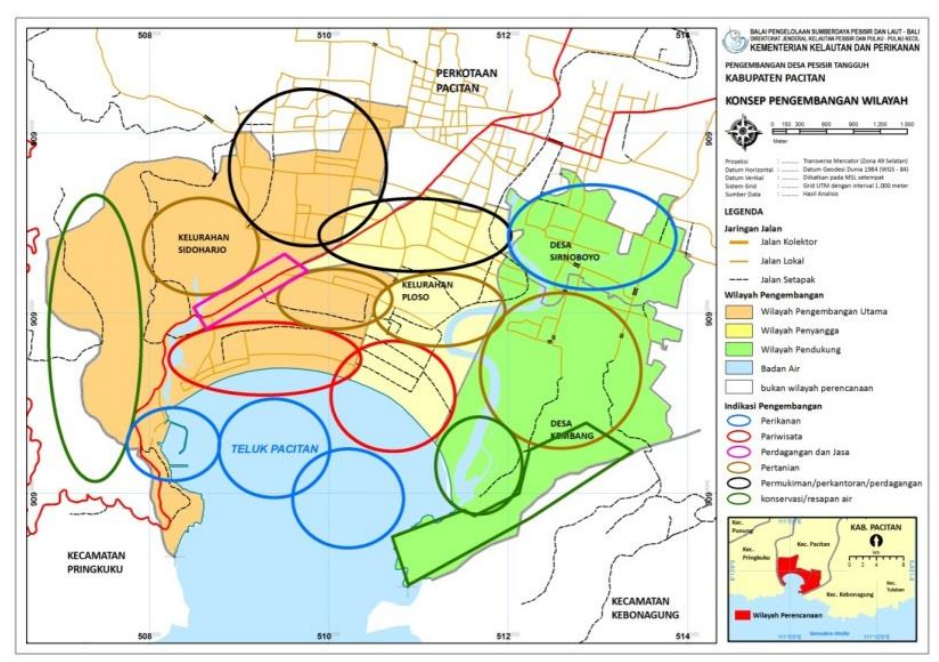

Gambar 2. Konsep Pengembangan Wilayah

Berdasarkan gambar 2 terlihat bahwa Desa Sirnoboyo menjadi desa Pusat Pelayanan Pendukung; yaitu Desa Sirnoboyo. Wilayah Desa Sirnoboyo yang berpusat di Dusun Ngemplak (Desa Sirnoboyo), sedangkan Dusun Krajan dan Suruhan pusat pengolahan hasil perikanan. Berdasarkan gambar di atas terlihat bahwa desa Sirnoboyo masuk dalam lingkaran biru yang memiliki jarak dari bibir pantai sekitar $2 \mathrm{~km}$ dan masuk dalam Desa pendukung atau masyarakat pesisir.. Walaupun tidak berbatasan langsung dengan garis pantai tetapi jika terjadi Tsunami Desa Sirnoboyo merupakan daerah terdampak Bencana Tsunami.

Masyarakat pesisir adalah sekumpulan masyarakat yang hidup bersamasama mendiami wilayah pesisir membentuk dan memiliki kebudayaan yang khas yang terkait dengan ketergantungannya pada pemanfaatan sumberdaya pesisir. Tentu masyarakat pesisir tidak saja nelayan, melainkan juga pembudidaya ikan, pengolah ikan bahkan pedagang ikan. Berikut ini aspek penting mengenai masyarakat pesisir :

Ditinjau dari aspek biofisik wilayah, ruang pesisir dan laut serta sumberdaya yang terkandung di dalamnya bersifat khas sehingga adanya intervensi manusia pada wilayah tersebut dapat mengakibatkan perubahan yang signifikan, seperti bentang alam yang sulit diubah, proses pertemuan air tawar dan air laut yang menghasilkan beberapa ekosistem khas dan lain-lain. Ditinjau dari aspek kepemilikan, wilayah pesisir dan laut serta sumberdaya yang terkandung di dalamnya sering memiliki sifat terbuka (open access). 
Ada empat permasalahan pokok yang terdapat di desa Pesisir di Indonesia, yakni tingginya tingkat kemiskinan masyarakat pesisir, pada tahun 2010 kemiskinan di desa-desa pesisir mencapai angka 7,8 juta jiwa, tingginya kerusakan sumberdaya alam pesisir, rendahnya kemandirian organisasi sosial desa dan lunturnya nilai-nilai budaya lokal dan rendahnya infrastruktur desa dan kesehatan lingkungan pemukiman. Keempat persoalan pokok ini juga memberikan andil terhadap tingginya tingkat kerentanan terhadap bencana alam dan perubahan iklim yang cukup tinggi pada desa-desa pesisir, terutama di wilayah pesisir pulau-pulau kecil.

Berdasarkan fakta di atas tersirat bahwa pemerintahan terkecil desa mempunyai kewajiban dalam rangka mewujudkan hak-hak masyarakat dengan merencanakan, membentuk, dan memulihkan masyarakat pasca bencana. Selain mengatur hak setiap warganegara juga mencantumkan kewajiban sebagai warga negara yang meliputi: setiap orang berkewajiban menjaga kehidupan sosial masyarakat yang harmonis, memelihara keseimbangan, keserasian, keselarasan, dan kelestarian fungsi lingkungan hidup; melakukan kegiatan penanggulangan bencana; dan memberikan informasi yang benar kepada publik tentang penanggulangan bencana. Selain hak yang harus dipenuhi oleh pemerintahan desa juga diatur tentang kewajiban warga negara dalam rangkan pengurangan resiko bencana alam. Peran aktif masyarakat dan pemerintahan harus senantiasa dihudupkan agar jika terjadi bencana yang datangnya kita tidak dapat menduganya bisa mengurangi resiko-resiko bencana.

Dalam rangka pelaksanaan di atas maka pemerintah desa Sirnoboyo mempunyai kewajiban dalam rangka kesiapsiagaan dalam menghadapi bencana yang senantiasa terintegrasi dalam perencanaan program pembangunan desa atau RPJMDesa (2013-2018). Dengan demikian semua program yang ada kaitannya dengan penanganan bencana alam khususnya banjir dan tsunami senantiasa direncanakan dan dicantumkab dalam RPJM Desa. Masyarakat desa hanya menulis dan merencanakan dalam RPJMDes yang selanjutnya akan akan ditindaklanjuti dengan membuat suatu perencanaan program yang akan diajukani pemerintah daerah maupun pusat. 


\section{Agoes Hendriyanto, Nimas Permata P, Menuju Desa...}

Selama tahun 2012, 2013 pemerintah desa Sirnoboyo mendapatkan bantuan anggaran dari Dinas Kelautan Republik Indonesia dalam bentuk bantuan dana pembangunan yang digunakan untuk kesiapsiagaan bencana. Dana tersebut dipergunakan untuk mengurangi resiko banjir di dua dusun yaitu dusun Ngemplak dan Suruhan yang selama ini pada saat musim hujan selalu terkena banjir sebagai akibat meluapnya sungai kebonagung yang masuk melalui pintu air yang rusak.

Desa/Kelurahan Tangguh Bencana adalah desa/kelurahan yang memiliki kemampuan mandiri untuk beradaptasi dan menghadapi ancaman bencana, serta memulihkan diri dengan segera dari dampak bencana yang merugikan, jika terkena bencana. Dengan demikian sebuah Desa/Kelurahan Tangguh Bencana adalah sebuah desa atau kelurahan yang memiliki kemampuan untuk mengenali ancaman di wilayahnya dan mampu mengorganisir sumber dayamasyarakat untuk mengurangi kerentanan dan sekaligus meningkatkan kapasitas demi mengurangi risiko bencana. Kemampuan ini diwujudkan dalam perencanaan pembangunan yang mengandung upaya-upaya pencegahan bencana yang diwujudkan dalam RPJM Desa Sirnoboyo 2013-2018 yang merupakan hasil dari perencanaan masyarakat Desa Sirnoboyo dalam acara Musrengbang desa Sirnoboyo yang berupa bangunan fisik maupun non fisik salah satunya dalam rangka pencegahan, kesiapsiagaan, pengurangan risiko bencana dan peningkatan kapasitas untuk pemulihan pasca keadaan darurat.

Di desa sirnoboyo yang termasuk daerah rawan tsunami telah direncanakan dan telah dilaksanakan upaya pencegahan, kesiapsiagaan dan pengurangan resiko yang dilakukan dengan bentuk memperbaiki pintu air, memperbaiki saluran air sepanjang satu kilometer di Dusun Ngemplak hal ini disebabkan karena disepenjang saluran air tersebut ada Sekolah Dasar Negeri Sirnoboyo III jika tidak segera dibangun akan mengakibatkan sekolah tersebut akan terkena imbas longsornya saluran air tersebut dan berdampak pada kegiatan belajar mengajar anak-anak sekolah Dasar. Selain itu dibuat papan petunjuk pengungsian jika terjadi tzunami dan di kasih peta rawan dan jalur evakuasi pada tempat-tempat yang strategis. Program ini bekerjasama dengan dinas kelautan dan Perikanan pusat yang dananya selama 2 tahun 500 juta. 
Untuk program tahun ketiga ini direncanakan untuk membuat pusat hasil olahan perikanan yang bertujuan untuk meningkatkan pendapatan masyarakat guna meningkatkan ketangguhan dalam menghadapi bencana dengan semakin meningkatnya swadaya masyarakat. Bentuk swadaya masyarakat yang diwujudkan dalam bentuk kerjabakti masih sangat tinggi. Untuk itu setiap kegiatan yang berhubungan dengan masyarakat yang dananya masih kurang perlu adanya swadaya tenaga kerja. Dengan demikian setiap program yang dilaksanakan di tiap Dusun di desa Sirnoboyo harus disesuaikan dengan karakteristik masyarakatnya dalam hal kemandirian.

Untuk itu memerlukan suatu pendekatan yang menyeluruh terhadap aspek kehidupan masyarakat desa Sirnoboyo sehingga setiap program pemerintah Desa Sirnoboyo dalam penanggulangan bencana dapat terlaksana dengan baik. Menurut (Soenyono, 2012: 32) untuk mengatasi ketidakberdayaan masyarakat hrus dilakukan dalam tataran sosial, ekonomi, budaya, dan politik. Sebenarnya dalam suatu pemerintahan baik di Kabupaten maupun propinsi sudah ada Departemen yang menangani sendiri. Masih kurangnya profesionalaisme, koordinasi sehingga program yang dicanangkan oleh masing- masing Departemen belum membuahkan hasil yang maksimal. hal ini tercermin dari tumpang tindihnya program pemerintah yang diperparah lagi prioritas pelaksanaan yang berbau politik.

Untuk daerah yang partisipasi masyarakatnya rendah perencanaan pembangunan yang menyangut dusun pemerintah desa akan mencari program yang bukan swakelola. Program non swakelola biasanya programnya akan terintegrasi dengan program lainnya yang langsung ditangani oleh proyek yang ditenderkan kepa pihak kedua. Anggaran yang dipergunakan mempergunakan anggaran daerah atau negara yang dananya sangat besar. Untuk gambar 1 terlihat bahwa bentuk partisipasi masyarakat dalam pemeliharaan aluran air irigasi sangat kurang hal ini akan berakibat pada saat musim banjir airnya akan meluap ke sawah yang akan berakibat terhadap rusaknya tanaman padi yang berada disekitar saluran air. Masyaraakat masih perlu kita tingkatkan kesadarannya 


\section{Agoes Hendriyanto, Nimas Permata P, Menuju Desa...}

dalam rangka memperbaiki saluran air khususnya tanggul yang berbatasan dengan sawahnya.

Sebenarnya suatu desa yang banyak peraturannya menandakan bahwa desa tersebut masyarakatnya banyak melakukan pelanggaran. Fungsi peraturan desa adalah untuk mengatur masyarakat berarti daerah tersebut perlu pengaturan karena sudah tidak teratur. Walaupun sangat bertentangan dengan definisi dalam Undang-undang bencana Alam bahwa yang dinamakan desa tangguh bencana harus memiliki peraturan desa dan memiliki perencanaan untuk penanganan bencana, dan memiliki anggaran yaang diwujudkan dalam peraturan desa. Untuk mewujudkan desa tangguh bencana diperlukan waktu sekitar 5 tahun dengan anggaran yang dibutuhkan setiap tahun sekitar 300 juta. Desa Sirinoboyo mulai membentuk Forum PRB (Pengurangan Risiko Bencana) tahun 2012 dan telah berjalan selama 2 tahun dan anggaran yang dibutuhkan sekitar 600 juta dari Program Desa pesisir Tangguh yang dimulai sejak tahun 2012. Targetnya untuk tahun 2015 desa Sirnoboyo menjadi Desa Tangguh Bencana.

Pembangunan berkelanjutan merupakan gagasan pembangunan untuk pemenuhan kebutuhan masyarakat pada masa sekarang yang dilakukan tanpa bertentangan dengan kepentingan generasi mendatang guna memenuhi kebutuhan mereka pada masa depan, senada dengan definisi pembangunan berkelanjutan versi WCED yaitu pembangunan yang memenuhi kebutuhan masa kini tanpa harus membatasi potensi untuk memenuhi kebutuhan dari generasigenerasi yang akan datang (Bencana dan Lingkungan, UNDP:1995). Dengan demikian, upaya-upaya PRB pada masa kini hendaknya tidak menciptakan bencana lain pada masa mendatang. Pembangunan berkelanjutan memperhitungkan 3 komponen pokok: (1) lingkungan, (2) sosial, dan (3) ekonomi. Tingkat keberlanjutan dari ketiga komponen ini saling terkait satu sama lain. Beberapa gagasan kunci dalam konsep pembangunan berkelanjutan adalah:

1. Pembangunan harus berwawasan jangka sangat panjang,

2. Pembangunan harus mempertahankan keberadaan sumberdaya alam dan fungsi lingkungan, 
Transformasi, Vol. 13, No. 1, Januari 2017: 1 - 13

3. Pembangunan harus ditujukan untuk mencapai keseimbangan yang tepat untuk memenuhi kebutuhan peningkatan kualitas hidup dengan pemanfaatan sumberdaya alam dan kelestarian sumberdaya alam itu sendiri, serta

4. Penerapan pembangunan menuntut adanya keadilan pada saat ini dan masa depan.

Upaya-upaya pengurangan risiko bencana berbasis komunitas diarahkan untuk menjadi bagian yang terpadu dalam perencanaan pembangunan (RPJMDes, RKP, APBDes) dan kebijakan-kebijakan sektoral. Demikian juga, setiap proses pengelolaan pembangunan harus memasukan unsur-unsur pengurangan risiko bencana. Integrasi tersebut dilaksanakan dalam proses-proses musrenbangdes, penyusunan, dan pengesahan yang secara aktif melibatkan seluruh anggota masyarakat.

Proses integrasi melalui tiga tahapan. Pertama, tahap input, dimulai dari penilaian masalah dan potensi desa menggunakan perangkat penilaian desa secara partisipatif/PRA (transek, sketsa desa, kalender musim, diagram kelembagaan), dalam tahap input ini masyarakat terlibat dalam diskusi membahas potensi, masalah, dan ancaman yang ada di desa yang menghasilkan daftar masalah dan potensi atau profil desa sebagai dasar penyusunan kebijakan dan program, profil risiko bencana desa menjadi pertimbangan untuk mengintegrasikan PRB dalam perencanaan pembangunan desa. Kedua, tahap proses, dengan melakukan lokakarya desa dengan pengelompokan masalah, pemeringkatan masalah, pengkajian alternatif tindakan, dan penyusunan program dan kegiatan pembanguman desa yang mengarusutamakan PRB dalam bidangbidang program yang selanjutnya dilakukan musrenbangdes untuk mengkonfirmasi, menggali input, dan memprioritaskan program. Ketiga, tahap hasil, setelah RPJM Desa direvisi berdasarkan saran dan masukan masyarakat Pemerintah Desa dan Badan Permusyawaratan Desa mengesahkan RPJM Desa.

Kegiatan ini juga disertai dengan peningkatan kapasitas pemerintahan desa guna mendorong terciptanya kebijakan-kebijakan yang mengarusutamakan PRB dengan memperbaharui profil dusun dan desa, pelatihan penyusunan RPJM Desa sesuai dengan Permendagri No. 66/2007 Tentang Perencanaan Pembangunan 
Desa, pelatihan penyusunan Perdes, dan Manajemen Pemerintahan Desa, serta pendampingan penyusunan RPJM Desa. Disamping hal diatas, untuk meningkatkan partisipasi perempuan dalam pembangunan dengan mengadakan pelatihan public speaking.

Berdasarkan Peraturan Kepala Badan Nasional Penanggulangan Bencana Nomor: 1 Tahun 2012 secara garis besar Desa Tangguh Bencana adalah desa yang memiliki kemampuan mandiri untuk beradaptasi dan menghadapi potensi ancaman bencana, serta memulihkan diri dengan segera dari dampak bencana yang merugikan. Desa Tangguh Bencana akan memiliki komponen-komponen sebagai berikut:

1. Legislasi: penyusunan Peraturan Desa yang mengatur pengurangan risiko dan penanggulangan bencana di tingkat desa

2. Perencanaan: penyusunan rencana Penanggulangan Bencana Desa; Rencana Kontinjensi bila menghadapi ancaman tertentu; dan Rencana; Aksi Pengurangan Risiko Bencana Komunitas (pengurangan risiko bencana menjadi bagian terpadu dari pembangunan)

3. Kelembagaan: pembentukan forum Penanggulangan Bencana Desa yang berasal dari unsur pemerintah dan masyarakat, kelompok/tim relawan penanggulangan bencana di dusun, RW dan RT, serta pengembangan kerjasama antar sektor dan pemangku kepentingan dalam mendorong upaya pengurangan risiko bencana

4. Pendanaan: rencana mobilisasi dana dan sumber daya (dari APBD Kabupaten/ Kota, APBDes/ADD, dana mandiri masyarakat dan sektor swasta atau pihakpihak lain bila dibutuhkan)

5. Pengembangan kapasitas: pelatihan, pendidikan, dan penyebaran informasi kepada masyarakat, khususnya kelompok relawan dan para pelaku penanggulangan bencana agar memiliki kemampuan dan berperan aktif sebagai pelaku utama dalam melakukan perencanaan, pelaksanaan, dan evaluasi kegiatan-kegiatan pengurangan risiko bencana Untuk program kegitan ini belum 100 persen terlaksana hal ini disebabkan anggaran desa tidak mencukupi. 
Transformasi, Vol. 13, No. 1, Januari 2017: 1 - 13

6. Penyelenggaraan Penanggulangan Bencana: kegiatan-kegiatan mitigasi fisik struktural dan non-fisik; sistem peringatan dini; kesiapsiagaan untuk tangggap darurat, dan segala upaya pengurangan risiko melalui intervensi pembangunan dan program pemulihan, baik yang bersifat struktural-fisik maupun nonstruktural. Kegiatan ini belum dilaksanakan secara maksimal.

Berdasarkian hasil wawancara dan observasi di desa Sirnoboyo dengan menggunakan 60 indikator yang terdapat di Dalam Peraturan Kepala Badan Nasional Penanggulangan Bencana Nomor: 1 Tahun 2012 Tanggal : 10 JanuarI 2012 Desa Tangguh Bencana Pratama dengan skor 31 dari 60 pilihan jawaban angket. Tingkat ini dapat dicapai oleh desa Sirnoboyo yang dicirikan dengan:

1. Adanya kebijakan PRB yang telah dilegalkan dalam bentuk Perdes atau perangkat hukum setingkat di Desa Sirnoboyo

2. Adanya dokumen perencanaan PB yang telah dipadukan ke dalam RPJMDes dan dirinci ke dalam RKPDes

3. Adanya forum PRB yang beranggotakan wakil-wakil masyarakat, termasuk kelompok perempuan dan kelompok rentan, dan wakil pemerintah desa/ kelurahan, yang berfungsi dengan aktif.

4. Adanya tim relawan PB Desa Sirnoboyo yang secara rutin terlibat aktif dalam kegiatan peningkatan kapasitas, pengetahuan dan pendidikan kebencanaan bagi para anggotanya dan masyarakat pada umumnya

5. Belum adanya upaya-upaya sistematis untuk mengadakan pengkajian risiko, managemen resiko, dan pengurangan kerentaan, termasuk kegiatan ekonomi produktif, alternatif untuk mengurangi kerentaan.

6. Belum adanya upaya-upaya sistematis untuk meningkatkan kapasitas kesiapsiagaan serta tanggap bencana.

\section{KESIMPULAN}

Yang menjadi permaslahan kaitannya dengan bencana alam yang disebabkan oleh perubahan iklim dalam rangka menjadikan desa Sirnoboyo menjadi Desa tangguh Bencana. Pada musim kemarau lahan pertanian di Desa Sirnoboyo banyak mengalami kekeringa karena sebagian besar merupakan sawah 
tadah hujan untuk itu memerlukan suatu penanganan yang serius guna membuat saluran irigasi sehingga air dari Sungai dapat dengan lancar masuk ke sawh yang pada akhirnya akan meningkatkan kesjahteraan masyarakat yang pada akhirnya akan menciptakan suatu kemandirian masyarakat.

Sering terjadinya bencana banjir sebagai akibat saluran drainase yang tidak berfungsi optimal sehingga memerlukan suatu dana untuk memperbaiki saluran air dan klep serta diesel untuk membuang kelebihan air karena saat banjir tinggi air sungai lebih tinggi dari pemukiman sehingga perlu adanya diesel untuk memompa air banjir. Selain itu juga daerah dusun Suruhan terjadi limpahan air banjir yang lebih tinggi jika dibandingkan dengan dusun lainnya sehingga memerlukan perahu karet dan pengungsian jika terjadi banjir hal ini untuk mengantisipasi meluapnya dua sungai yaitu grindulu dan Kebonagung.

Selama ini sudah banyak suatu program dari pemerintah kaitannya dengan penanggulangan bencana tetap hanya sebatas pembentukan kelompok tetapi pada tataran implementasinya di lapangan masih sangat jauh ari harapan yang diingikan masyarakat.

\section{DAFTAR PUSTAKA}

BNPB. 2012. Peraturan Kepala Badan Nasional Penanggulangan Bencana Nomor 1 Tahun 2012. Jakarta

Peraturan Menteri Dalam Negeri No. 66 Tahun 2007 Tentang Perencanaan Pembangunan Desa

Soenyono. 2012. Sosiologi Pemberdayaan Masyrakat (Community Empowerment). Surabaya: Jenggala Pustaka Utama.

Pemerintah Desa Sirnoboyo. 2012. Program Pengembangan Desa Pesisir Tangguh (PDPT)Kabupaten Pacitan.Undang-Undang Republik

Indonesia Nomor 24 Tahun 2007 Tentang Penanggulangan Bencana.

Undang No. 25 Tahun 2004 Tentang Sistem Perencanaan Pembangunan Nasional. 